\title{
KONTRIBUSI PUSTAKAWAN UNIVERSITAS GADJAH MADA PADA JURNAL "MEDIA INFORMASI" .
}

\author{
Oleh \\ Pergola Irianti ${ }^{*}$
}

\begin{abstract}
This study aimed to determine librarian Universitas Gadjah Mada contribution at journal "Media Informasi". Quantitative descriptive approach were used in this study, and data were collected by documentation technique. The subject of this study are "Media Informasi" published in 1996-2012, all the articles and authors as an objects. The analysis data based on the percentage provided on the table.

The results showed that the Media Informasi published in 1996-2012, there are $76.53 \%$ authors from UGM and $23.57 \%$ from outside the UGM. Articles topics of librarian (library human resources) earned the highest ranking (23.95\%), and the topic of library institutions in the second rank (22.39\%). While the contribution of the author is still around "the author contributed one article", however there is an author who contributed almost 20 articles in that publication period.
\end{abstract}

Key words: author contribution, article.

*) Pustakawan UGM

\section{A. PENDAHULUAN}

Lingkungan kerja pustakawan tidak pernah jauh dari sumber informasi. Mereka memiliki kesempatan yang luas untuk membaca dan memahami sebuah sumber informasi. Apabila kesempatan tersebut dimanfaatkan dengan sebaik-baiknya, banyak pengetahuan dan keuntungan yang mereka dapatkan. Lebih dari itu sebuah sumber informasi dapat menginspirasi pembaca untuk menulis, mencurahkan pengalaman dan pengetahuan yang mereka miliki. Pustakawan yang memanfaatkan kesempatan ini, berpeluang mempublikasikan hasil karya atau tulisannya pada sumber informasi berupa majalah atau media cetak lokal maupun regional bahkan internasional. Hasil karya yang telah dipublikasikan pada majalah dapat diperhitungan sebagai kredit poin untuk kenaikan jabatan pustakawan.

Perhatian institusi perpustakaan terhadap sumber daya manusia atau pustakawan dalam mendukung pencapaian tujuan perpustakaan, tidak terbatas pada pemberian insentif kinerja. Apresiasi dapat juga diberikan dalam bentuk penyediaan fasilitas mengikuti pelatihan pengembangan diri, pelatihan atau kursus bahasa asing, dan pelatihan-pelatihan lain yang mendukung tugas sehari-hari.
Penerbitan majalah atau buletin oleh institusi perpustakaan dapat menampung ekspresi anggota institusi dalam hal ini pustakawan untuk berbagi pengetahuan, pengalaman, dan sebagainya. Pustakawan diberi kesempatan seluas-luasnya untuk menyampaikan informasi, pengetahuan, pengalaman, bahkan gagasan-gagasan mereka mengenai kepustakawanan. Meskipun demikian, rambu-rambu harus tetap ditegakkan agar penerbitan media tersebut sesuai dengan norma yang berlaku pada umumnya.

Menyadari betapa pentingnya manfaat penerbitan sebuah media, perpustakaan Universitas Gadjah Mada sejak tahun 1990-an telah menerbitkan media atau publikasi yang dapat menampung ekspresi pustakawan berupa tulisan atau pengalaman terkait dengan bidang kepustakawanan. Publikasi tersebut bernama "Media Informasi" dan sampai saat ini masih diterbitkan secara rutin. Media Informasi telah menampung tulisan pustakawan di lingkungan UGM bahkan penulis dari luar UGM yang ingin berkontribusi dalam penerbitan tersebut. Telah dipublikasikan 38 nomor penerbitan Media Informasi periode 1996-2012 yang memuat tulisan pustakawan dari dalam dan luar UGM. Dalam tulisan ini penulis mengkaji tiga hal sebagai berikut: 
(1) Bagaimana kontribusi pustakawan UGM sebagai pengarang artikel yang dimuat pada Media Informasi terbitan tahun 1996 2012 ?

(2) Adakah pengarang yang produktif . menyumbangkan artikelnya pada Media Informasi terbitan tahun 1996-2012?

(3) Topik-topik artikel apakah yang dimuat pada Media Informasi terbitan tahun 19962012?

Tujuan kajian ini untuk:

(1) Mengetahui prosentase jumlah pengarang artikel Media Informasi periode 1996-2012 yang berasal dari dalam dan luar UGM.

(2) Mengetahui pengarang yang produktif menyumbangkan artikel pada Media Informasi tahun 1996-2012.

(3) Mengetahui topik-topik artikel yang dimuat pada Media Informasi tahun 19962012.

Manfaat yang diharapkan dari kajian ini antara lain untuk menambah khazanah kajian bidang perpustakaan dan sebagai bahan masukan "dalam evaluasi penerbitan Media Informasi selanjutnya. Diharapkan pula kajian ini dapat memacu pustakawan UGM berpartisipasi dengan menyumbangkan artikel pada Media Informasi.

\section{B. TINJAUAN PUSTAKA DAN LANDASAN TEORI}

Kajian terhadap majalah atau jurnal ilmiah telah banyak dilakukan baik di dalam maupun luar negeri. Kajian yang terkait dengan majalah atau jurnal pada umumnya berupa kajian bibliometri.

Beberapa kajian bibliometri di luar negeri, antara lain mengenai kolaborasi yang pernah dilakukan oleh Kaur (2005) berupa kajian terhadap artikel pada Malayan Law Journal. Patra dan Chand (2006) mengenai studi bibliometri pada literatur penelitian perpustakaan dan informasi di India dengan menggunakan abstrak dari Library and Information Science Abstracts (LISA). Biswas (2007) mengenai kepengarangan kolaborasi pada jurnal Economic Botany 1994-2003. Kajian mengenai produktivitas pengarang pernah dilakukan Raptis (1992) dan Walker (1997) keduanya menemukan bahwa pengarang yang menghasilkan lebih dari satu artikel hanya sedikit. Sementara pada pada tahun 1999, penelitian yang dilakukan oleh Lipetz terhadap majalah JASIS menunjukkan ada kecenderungan meningkatnya produktivitas pengarang.

Di Indonesia, beberapa peneliti yang melakukan kajian terhadap majalah atau jurnal antara lain Prihanto (2002) pada tahun 1996 melakukan kajian mengenai tingkat kolaborasi peneliti dengan menggunakan sumber data dari majalah, warta, dan prosiding pada KKIT LAPAN tahun 1975-1994. Rufaidah (2008), mengenai kolaborasi dan graf komunikasi dengan data kajian bersumber pada jurnal. Kedua peneliti di atas mengkaji tentang kolaborasi penelitian yang dimuat pada majalah atau jurnal. Penelitian terbaru dilakukan oleh Maryono dan Junandi (2012) mengenai analisis kolaborasi dan institusi pada Indonesian Journal of Chemistry penerbitan 2007-2011.

Meskipun beberapa kajian terhadap majalah dan jurnal di Indonesia pernah dilakukan, tetapi sepanjang pengetahuan penulis kajian terhadap Media Informasi yang diterbitkan oleh Perpustakaan UGM belum pernah dilakukan. Oleh karena itu pada kesempatan ini, penulis mencoba melakukan kajian terhadap Media Informasi periode 19962012.

\section{Bibliometri}

Istilah bibliometrics atau bibliometrika pertama kali diusulkan oleh Pritchard (SulityoBasuki, 2002) sebagai pengganti istilah "statistical bibliography" yaitu aplikasi metode statistika dan matematika terhadap buku serta media komunikasi lainnya. Media komunikasi yang dimaksud dapat berbentuk cetakan (grafis) maupun elektronik.

Masih menurut Sulistyo-Basuki (2002), bibliometri bertujuan menjelaskan proses komunikasi tertulis dan sifat serta arah pengembangan sarana deskriptif penghitungan dan analisis berbagai faset komunikasi. Ada dua kelompok bibliometri yaitu bibliometri deskriptif dan bibliometri perilaku. Bibliometri deskriptif menggambarkan karakteristik atau ciri sebuah literatur, sedangkan bibliometri perilaku mengkaji hubungan yang terbentuk antara komponen literatur.

Pada umumnya objek utama kajian bibliometrika berupa majalah, dikarenakan majalah merupakan media komunikasi ilmiah 
yang paling penting, merupakan pengetahuan publik, dan arsip umum yang dapat dibaca setiap saat oleh masyarakat. Parameter yang tidak dapat dilepaskan dari ciri majalah antara lain: pengarang, judul artikel, judul majalah, tahun terbit, daftar pustaka (referensi), sitiran (literatur yang dimuat dalam daftar pustaka, dan deskriptor (Sulistyo-Basuki, 2002).

\section{Artikel, kepengarangan, dan topik artikel majalah}

Pengertian artikel menurut Lasa (2009), adalah karangan seseorang atau lebih dalam topik tertentu yang dimuat dalam ensiklopedi, majalah, jurnal, surat kabar, atau terbitan lain dengan tujuan untuk menyampaikan gagasan, ide, atau fakta guna mendidik, menambah wawasan, menawarkan solusi, atau menghibur. Dikemukakan pula bahwa dalam penulisan artikel ada beberapa hal yang harus diperhatikan dan salah satunya adalah berfokus pada satu tema. Lebih lanjut Lasa (2009) mengemukakan bahwa pengarang artikel adalah orang atas nama pribadi, lembaga maupun badan korporasi secara sendirian maupun kelompok menyiapkan dan menuangkan gagasan, ide, pemikiran, dan pengalaman ke dalam bentuk karya intelektual maupun artistik. Termasuk dalam kategori ini adalah penulis, penyusun, pelukis, pemahat, penyusun bunga rampai, pengarang pencipta lagu, komponis dan lainnya dan bertanggung jawab terhadap isi karya.

Topik artikel adalah pokok pikiran yang dipakai sebagai dasar dalam membuat artikel. Artikel-artikel yang dibuat berdasarkan pokok pikiran kepustakawanan, maka artikel tersebut termasuk dalam topik kepustakawanan. Kepustakawanan adalah segala sesuatu yang terkait dengan perpustakaan, sumber daya manusia (pustakawan), koleksi dan lain-lain. Topik-topik kepustakawanan ini terbagi atas subtopik-subtopik yang lebih terbatas lingkupnya. Ditinjau dari sudut pandang penyelenggaraan perpustakaan, sebuah perpustakaan harus memenuhi beberapa aspek. Aspek-aspek tersebut meliputi: koleksi, layanan, sumber daya manusia, fasilitas dan peralatan, serta teknologi informasi (Ditjen Dikti, 2005). Sudut pandang yang lain menurut Septiyantono dan Sidik (2003), perpustakaan sebagai sebuah sistem, di dalamnya harus terdapat unsur tempat atau institusi, koleksi, dan pengguna. Menurut Sudarsono (2010), aspek pustakawan sebagai profesi yang menjadi salah satu aspek penyelenggaraan perpustakaan, perlu menjalin komunikasi dengan lembaga kepustakawanan yang lain seperti lembaga pendidikan pustakawan dan organisasi profesi pustakawan.

Dalam perkembangan selanjutnya, untuk menjaga eksistensi perpustakaan perlu dilakukan evaluasi yang konsisten. Proses evaluasi dapat dilakukan melalui koleksi atau melibatkan pengguna. Evaluasi perpustakaan melalui koleksi dapat dilakukan dengan teknik bibliometri. Bibliometri merupakan analisis kuantitatif terhadap bibliografi dan kepustakaan (Sulistyo-Basuki, 2002).

Berdasarkan uraian tersebut, diasumsikan bahwa topik kepustakawanan tidak lepas dari unsur-unsur meliputi: institusi atau lembaga perpustakaan, koleksi perpustakaan dan pengolahannya, sumber daya manusia perpustakaan (pustakawan), pengguna perpustakaan (pemustaka), sistem layanan, teknologi informasi, lembaga pendidikan pustakawan, organisasi profesi pustakawan, dan bibliometri.

\section{METODE}

Metode yang digunakan dalam kajian ini adalah metode deskriptif, yaitu pengukuran yang cermat terhadap fenomena atau permasalahan yang ada. Dalam hal ini peneliti mengembangkan konsep dan menghimpun fakta, tetapi tidak melakukan pengujian hipotesis (Effendi, 2012).

Populasi dalam kajian ini adalah artikel yang dimuat pada publikasi Media Informasi periode 1996-2012. Seperti dikemukakan oleh Arikunto (2010) bahwa populasi merupakan keseluruhan subjek penelitian. Apabila seseorang ingin meneliti semua elemen yang ada dalam wilayah penelitian maka penelitiannya merupakan penelitian populasi.

Metode pengumpulan data menggunakan metode dokumentasi, yaitu mencari data mengenai hal-hal atau variabel berupa catatan, transkrip, buku, surat kabar, majalah, prasasti, notulen rapat dan sebagainya. Metode ini tidak begitu sulit, data tidak mudah berubah karena dokumentasi yang diamati adalah benda mati (Arikunto, 2010). Data kajian ini diperoleh 
dalam publikasi Media Informasi yang terbit pada periode 1996-2012. Dalam pengumpulan data ini dilakukan langkah-langkah sebagai berikut:

1. Mengumpulkan semua terbitan Media Informasi periode 1996-2012.

2. Pembuatan lembar kerja dalam bentuk tabel yang terdiri atas kolom-kolom untuk: nomor publikasi, jumlah artikel yang dimuat, judul artikel, nama pengarang artikel, asal instansi pengarang, frekuensi pengarang menulis artikel yang dimuat pada publikasi tersebut.

3. Pembuatan lembar kerja dalam bentuk tabel yang terdiri atas kolom-kolom untuk: judul artikel dan kolom penentuan topik artikel. Pada kolom penentuan topik, ada sembilan kelompok topik artikel meliputi:
(a)
perpustakaan
(institusi),
(b) pustakawan, (c) koleksi dan pengolahan, (d) layanan, (e) pengguna, (f) teknologi informasi, (g) lembaga pendidikan pustakawan, (h) organisasi profesi pustakawan, (i) bibliometri, dan (j) lainlain merupakan kolom tambahan sebagai alternatif terakhir apabila topik artikel tidak masuk dalam sembilan kelompok yang telah ditentukan tersebut.

Selanjutnya dilakukan analisis data dengan cara melakukan tabulasi data yang telah dimasukkan dalam lembar kerja berdasarkan kelompoknya. Hasil selanjutnya disajikan dalam bentuk tabel frekuensi dan presentase. Keseluruhan proses analisis data dilakukan dengan bantuan program Microsoft-Excel.

\section{HASIL DAN PEMBAHASAN}

\section{Instansi asal pengarang artikel Media Informasi periode 1996-2012}

Informasi mengenai instansi asal pengarang diperoleh dari keterangan yang tertulis pada halaman pertama setiap judul artikel. Berdasarkan data yang terkumpul untuk periode penerbitan Media Informasi 1996-2012, terdapat 37 nomor penerbitan, dengan jumlah artikel sebanyak 192 judul.

Berdasarkan instansi asal pengarang artikel, diperoleh data jumlah pengarang artikel yang berasal dari dalam UGM sebanyak 150 orang, dan 46 orang berasal dari luar UGM. Hal ini menunjukkan bahwa kepengarangan artikel pada Media Informasi periode 1996-2012 didominasi oleh pengarang yang berasal dari UGM. Rincian selengkapnya dapat dilihat pada tabel 1.

Tabel 1

Jumlah pengarang artikel Media Informasi periode 1996-2012 berdasarkan asal instansi

\begin{tabular}{|c|c|c|c|c|c|c|c|c|}
\hline \multirow{3}{*}{$\begin{array}{l}\text { Tahun } \\
\text { terbit }\end{array}$} & \multirow{3}{*}{$\begin{array}{l}\text { Jumlah } \\
\text { terbitan }\end{array}$} & \multicolumn{3}{|c|}{ Jumlah } & \multicolumn{4}{|c|}{ Asal instansi pengarang } \\
\hline & & \multicolumn{2}{|c|}{ Artikel } & \multirow{2}{*}{$\begin{array}{c}\text { Penga- } \\
\text { rang }\end{array}$} & \multicolumn{2}{|c|}{ Dalam UGM } & \multicolumn{2}{|c|}{ Luar UGM } \\
\hline & & Jml & $\%$ & & $\mathbf{I m l}$ & $\%$ & $\mathrm{JmI}$ & $\%$ \\
\hline 1996 & 2 & 17 & 8,80 & 17 & 15 & 7,65 & 2 & 1,02 \\
\hline 1997 & 3 & 24 & 12,43 & 24 & 22 & 11,22 & 2 & 1,02 \\
\hline 1998 & 1 & 7 & 3,62 & 7 & 7 & 3,57 & 0 & 0 \\
\hline 1999 & 2 & 10 & 5,18 & 10 & 8 & 4,08 & 2 & 1,02 \\
\hline 2000 & 3 & 16 & 8,29 & 16 & 3 & 1,54 & 13 & 6,63 \\
\hline 2001 & 4 & 22 & 11,39 & 23 & 18 & 9,18 & 5 & 2,55 \\
\hline 2002 & 1 & 4 & 2,07 & 4 & 4 & 2,04 & 0 & 0 \\
\hline 2003 & 3 & 18 & 9,32 & 18 & 13 & 6,63 & 5 & 2,55 \\
\hline 2004 & 3 & 14 & 7,25 & 15 & 8 & 4,08 & 7. & 3,57 \\
\hline 2005 & 3 & 11 & 5,69 & 11 & 10 & 5,10 & 1 & 0,51 \\
\hline 2006 & 3 & 11 & 5,69 & 12 & 10 & 5,10 & 2 & 1,02 \\
\hline 2007 & 2 & 7 & 3,62 & 7 & 7 & 3,57 & 0 & 0 \\
\hline 2008 & 1 & 4 & 2,07 & 6 & 6 & 3,06 & 0 & 0 \\
\hline 2009 & 2 & 9 & 4,66 & 9 & 9 & 4,59 & 0 & 0 \\
\hline 2010 & 2 & 10 & 5,18 & 10 & 5 & 2,55 & 5 & 2,55 \\
\hline 2011 & 1 & 4 & 2.07 & 4 & 3 & 1,53 & 1 & 0,51 \\
\hline 2012 & 1 & 4 & 2,07 & 4 & 3 & 1,53 & 1 & 0,51 \\
\hline Jumlah & 37 & 192 & 100 & 196 & 150 & 76,53 & 46 & 23,47 \\
\hline
\end{tabular}


Tabel 1 menunjukkan bahwa jumlah pengarang artikel yang berasal dari dalam UGM sebesar $76,53 \%$ dan sebesar $23,47 \%$ beråsal dari luar UGM. Pengarang artikel pada Media Informasi periode 1996-2012 didominasi oleh sivitas akademika terutama pustakawan di lingkungan UGM. Meskipun demikian pada penerbitan tahun 2000, didominasi oleh pengarang dari luar UGM sebesar 6,63\%.

\section{Pengarang yang produktif menyumbangkan artikel}

Berdasarkan data yang terkumpul diperoleh hasil bahwa pengarang artikel yang paling tinggi kontribusinya dalam menulis artikel pada Media Informasi 1996-2012 adalah Lasa Hs pada peringkat pertama yaitu sebanyak 18 artikel, kemudian diikuti oleh Sri Rumani yang berpartisipasi dengan sembilan artikel. Pada peringkat di bawahnya adalah Purwono, Supriyono, dan Uminurida Suciati masingmasing dengan tujuh artikel yang dikontribusikan untuk Media Informasi pada periode tersebut. Pada peringkat ke empat adalah Ida Fajar Priyanto dan Sri Rohyanti Zulaikha masing-masing berkontribusi dengan enam artikel.

Grafik perbandingan jumlah artikel dan kontributor (pengarang) pada Media Informasi periode penerbitan 1996-2012 dapat dilihat pada gambar 1 .
Gambar 1. Grafik perbandingan jumlah artikel dan kontributor (pengarang) yang berkontribusi pada Media Informasi periode penerbitan 1996-2012

Gambar 1 menunjukkan bahwa pada periode penerbitan Media Informasi tahun 1996-2012, hanya ada satu orang pengarang (kontributor) yang dapat menyumbangkan artikelnya mendekati angka 20, dan sebaliknya ada sekitar 60 orang pengarang (kontributor) yang menyumbangkan artikelnya meskipun masing-masing hanya berkontribusi satu artikel.

Meskipun Perpustakaan UGM sudah memfasilitasi sebuah publikasi yang dapat menampung tulisan berupa gagasan, pandangan, bahkan kritikan terkait dengan kepustakawanan dalam lingkungan internal maupun eksternal, tampaknya respon pustakawan khususnya di lingkungan UGM masih sangat rendah. Hasil kajian ini mendukung penelitian Suciati (1999) yang mengemukakan bahwa kebiasaan menulis pada pustakawan di Indonesia masih sangat minim. Menurut Sumantri (2004), minat dan lingkungan yang mencintai kegiatan baca-tulis perlu dipupuk dengan pembekalan penguasaan terhadap teknik menulis para pustakawan.

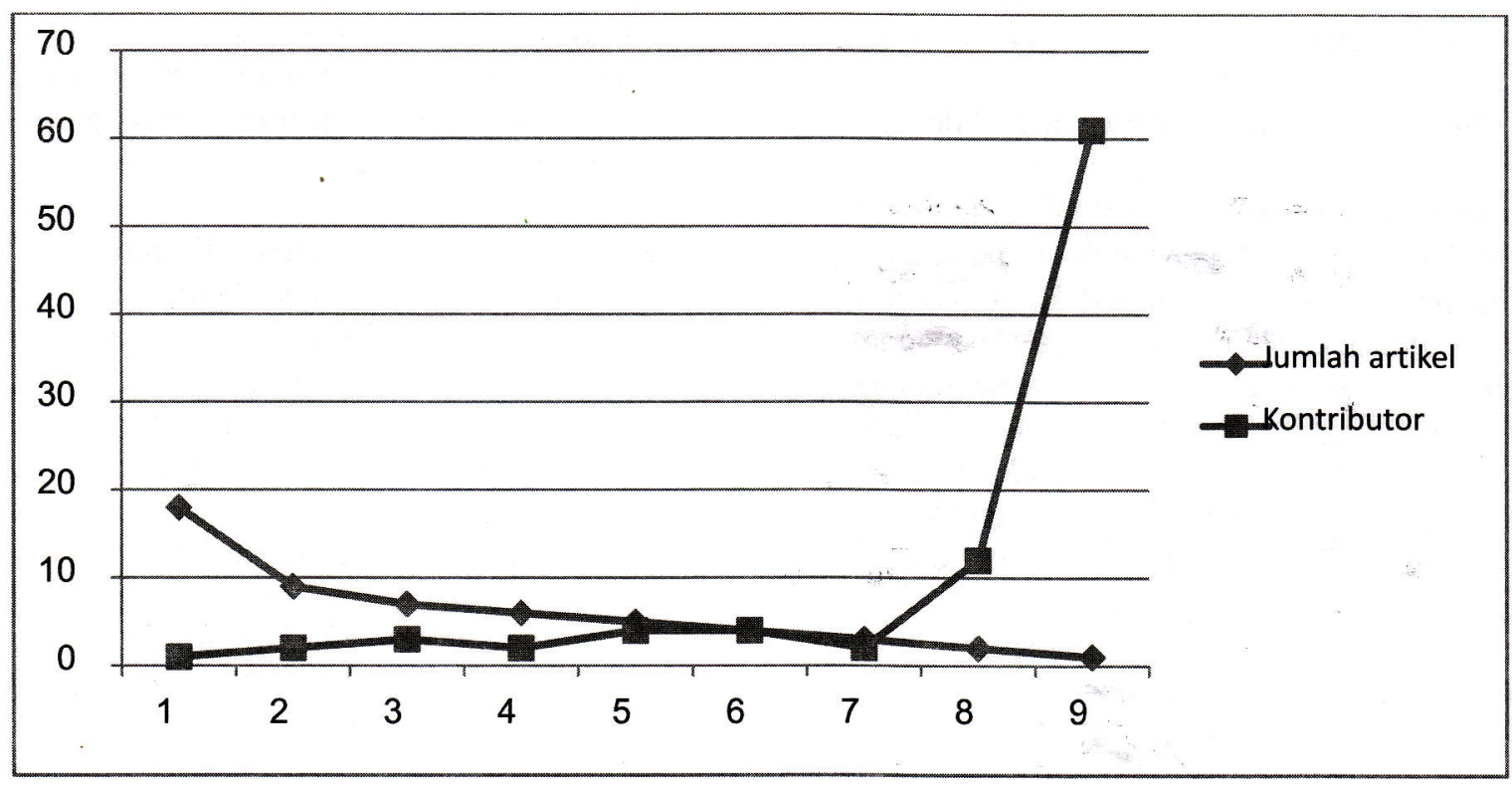


3. Topik artikel pada Media Informasi periode penerbitan 1996-2012

Pada kajian ini ada sembilan kelompok topik yang dipergunakan sebagai dasar pengelompokan artikel pada Media Informasi periode 1996-2012. Sembilan kelompok topik tersebut meliputi: (a) perpustakaan, (b) pustakawan, (c) koleksi dan pengolahan, (d) sistem layanan, (e) pengguna (f) teknologi informasi, (g) lembaga pendidikan pustakawan, (h) organisasi profesi pustakawan, (i) bibliometri, dan (j) lain-lain merupakan tambahan apabila topik artikel tidak dapat masuk pada salah satu kelompok yang telah ditentukan.

Berdasarkan data yang terkumpul, diperoleh hasil seperti tercantum pada tabel 2 berikut.

Tabel 2

Topik artikel yang dimuat pada Media Informasi periode 1996-2012

\begin{tabular}{clrr}
\hline No. & \multicolumn{1}{c}{ Topik Artikel } & Jumlah & \multicolumn{1}{c}{$\%$} \\
\hline 1 & Institusi perpustakaan & 43 & 22,39 \\
2 & Koleksi dan pengolahan & 24 & 12,50 \\
3 & Pustakawan dan sumber & 46 & 23,95 \\
& daya manusia & & \\
4 & Sistem layanan & 24 & 12,50 \\
5 & Pengguna perpustakaan & 0 & 0 \\
6 & Teknologi informasi & 27 & 14,06 \\
7 & Lembaga pendidikan & 2 & 1.04 \\
& pustakawan & & \\
8 & Organisasi profesi & 3 & 1,56 \\
& pustakawan & & \\
9 & Bibliometrika & 1 & 0,52 \\
10 & Lain-lain & 22 & 11,45 \\
\hline \multicolumn{2}{c}{ Jumlah } & 192 & 100 \\
\hline & $\quad$ & &
\end{tabular}

Pada tabel 2 terlihat bahwa artikel dengan topik "pustakawan dan sumber daya manusia perpustakaan" menduduki peringkat tertinggi sebesar $23,95 \%$, dan peringkat di bawahnya topik mengenai "institusi perpustakaan" sebesar $22,39 \%$. Peringkat berikutnya topik mengenai teknologi informasi sebesar $14,06 \%$. Sementara artikel dengan topik "koleksi dan pengolahan" serta "sistem layanan" berada pada ranking yang sama masing-masing sebesar $12,50 \%$.

Kondisi di atas menunjukkan bahwa artikel dengan topik pustakawan, institusi perpustakaan, dan teknologi informasi lebih diminati oleh para kontributor artikel dalam Media Informasi periode 1996 - 2012.
Sementara topik artikel yang membahas mengenai "pengguna perpustakaan" sama sekali tidak diminati oleh para kontributor, demikian halnya dengan topik bibliometri.

Tinggi rendahnya perolehan angka prosentase pada topik-topik artikel diasumsikan karena beberapa alasan antara lain: kurangnya minat dan pustaka pendukung untuk membuat tulisan dengan topik-topik tertentu.

\section{E. KESIMPULAN DAN SARAN}

Berdasarkan hasil kajian di atas dapat disimpulkan bahwa publikasi Media Informasi yang diterbitkan oleh Perpustakaan UGM periode 1996-2012, telah memberi peluang kepada pustakawan di lingkungan UGM dan masyarakat umum pemerhati perpustakaan. Pada periode penerbitan tersebut, ada 192 artikel yang ditulis oleh 196 pengarang. Sebesar $76,53 \%$ pengarang berasal dari lingkungan UGM dan selebihnya $23,47 \%$ dari luar UGM. Dengan demikian partisipasi pengarang dalam hal ini pustakawan UGM lebih besar daripada pengarang yang berasal dari luar UGM.

Topik-topik artikel yang dimuat pada Media Informasi 1996-2012 masih berorientasi pada topik pustakawan $(23,95 \%)$ dan institusi perpustakaan $(22,39 \%)$. Sementara kontribusi pengarang dalam menulis artikel pada Media Informasi periode tersebut, masih berkisar "satu pengarang menulis satu artikel". Meskipun demikian ada seorang pengarang yang menulis 18 artikel pada penerbitan Media Indormasi periode 1996-2012. Kondisi ini menunjukkan bahwa kebiasaan menulis pada pustakawan masih sangat rendah.

Rekomendasi yang dapat disampaikan untuk Perpustakaan UGM antara lain:

1. Mempertahankan penerbitan Media Informasi, sebagai media komunikasi pustakawan UGM khususnya dan pemerhati kepustakawanan pada umumnya.

2. Memberi kesempatan seluas-luasnya kepada pustakawan untuk mengikuti pelatihan yang berkaitan dengan teknik menulis artikel atau menyusun karya ilmiah. 


\section{DAFTAR PUSTAKA}

Arikunto, S. 2010. Prosedur penelitian: suatu pendekatan praktik. Jakarta: Rineka Cipta.

Biswas, $\mathrm{BC}$ et al. 2007. Economic Botany: a Bibliometric Study. Malaysian Journal of Library and Information Science. Volume 12, No. 1. (23-33).

Ditjen Dikti. 2005. Perpustakaan Perguruan Tinggi, Edisi ketiga. Jakarta: Depdiknas RI Ditjen Dikti.

Effendi, S. 2012. Metode penelitian survai. Jakarta: LP3ES.

Kaur, H. 2005. Bibliometric Study of Malayan Law Journal Articles. Kekal Abadi, Vol. 24 , No. $1 \& 2$.

Lasa Hs. 2009. Kamus Kepustakawanan Indonesia.Yogyakarta: Pustaka Book Publisher.

Lipetz, B. 1999. Aspects of JASIS authorship through five decades. Journal of American Society for Information Science, 50 (11): 994-1003.

Maryono dan Sri Junandi. 2012. Indonesian Journal of Chemistry 2007-2011: analisis kolaborasi dan institusi. Visi Pustaka, Volume 14, (3): 13-23.

Patra, SK \& Chand, P. 2006. Library and information science research in India: A Bibliometric Study. Annals of Library and Information Studies. Volume 53, (219-223)

Prihanto, I.G. 2002. Kolaborasi. Dalam Kumpulan Makalah Kursus Bibliometrika. Depok: Masyarakat Informatika Indonesia.

Raptis, P. 1992. Authorshipcharacteristics in five international library science journal. Libry 47: 35-52.

Rufaidah, VW. 2008. Kolaborasi dan graf komunikasi artikel ilmiah peneliti bidang pertanian: Studi kasus pada jurnal penelitian dan pengembangan pertanian serta Indonesia Journal of Agricultural Science. Jurnal Perpustakaan Pertanian, Volume 17, (1): 10-21.

Septiyantono, T. dan Sidik, U. 2003. Dasardasar Ilmu Perpustakaan dan Informasi.. Yogyakarta: Jurusan Ilmu Perpustakaan dan Informaai Fakultas Adab IAINSUKA.
Suciati, T.M. 1999. Minat dan kebiasaan menulis pustakawan sebagaimana tercermin pada majalah ilmiah perpustakaan terbitan Indonesia. (http://lontar.ui.ac.id/opac /themes/ libri2/detail. $=20159284$ \&lokasi $=$ lokal .

Sudarsono, B. 2010. Kepustakawanan. Makalah. Tidak diterbitkan

Sulistyo-Basuki. 2002..Bibliometrika, sainsmetrika dan informetrika. Dalam Kumpulan Makalah Kursus. Bibliometrika, 20 - 23 Mei. Depok: Masyarakat Informetrika Indonesia

Sumantri, U.P. 2004. Motivasi pustakawan dalam menulis karya tulis ilmiah yang dipublikasikan (Survei di Pusat Perpustakaan dan dan Penyebaran Teknologi Pertanian). Journal Perpustakaan Pertanian, Volume 13, (2): 41-46:

Walker, TD. 1997. Journal of documentary reproduction, 1938-1941: domain as reflected in characteristics of authorship and citation. Journal of American Society for Information Science, 48 (4): 361-368 